\title{
Structure and Evolution of the Lithosphere Beneath the Rocky Mountains: Initial Results from the CD-ROM Experiment
}

\section{CD-ROM Working Group*}

\section{ABSTRACT}

An integration of new seismic reflection, seismic refraction, teleseismic, and geological data provides insights into the nature and evolution of the lithosphere along a transect extending from Wyoming to New Mexico. Perhaps the major issue in interpreting the seismic data is distinguishing lithospheric structures that formed during Precambrian growth and stabilization of the continent from those that record Cenozoic tectonism. Tomographic data show that the upper mantle, to depths of $>200 \mathrm{~km}$, contains several dipping velocity anomalies that project up to overlying Proterozoic crustal boundaries. Our integrated studies define crustal sutures that are congruent with the dipping mantle domains, and we interpret these crust and mantle features as the signatures of Proterozoic paleosubduction zones. Proposed sutures are the Cheyenne belt, Lester-Farwell Mountain area of northern Colorado, and Jemez lineament. The resulting thick Proterozoic lithosphere was part of North America by $1.6 \mathrm{Ga}$, and has remained both fertile and weak as shown by repeated deformational and magmatic reactivations from 1.4 Ga to present.

Proterozoic lithosphere of Colorado and New Mexico differs from lithosphere beneath the Archean core of the continent, possibly in thickness but most important by its strongly segmented nature, its longterm fertility for magmatism, and its rela-

\footnotetext{
*CD-ROM (Continental Dynamics of the Rocky Mountains) Working Group: K.E. Karlstrom (corresponding author, Department of Earth and Planetary Sciences, University of New Mexico, Albuquerque, NM, 87108, kek1@unm.edu), S.A. Bowring, K.R. Chamberlain, K.G. Dueker, T. Eshete, E.A. Erslev, G.L. Farmer, M. Heizler, E.D. Humphreys, R.A. Johnson, G.R. Keller, S.A. Kelley, A. Levander, M.B. Magnani, J.P. Matzel, A.M. McCoy, K.C. Miller, E.A. Morozova, F.J. Pazzaglia, C. Prodehl, H.-M. Rumpel, C.A. Shaw, A.F. Sheehan, E. Shoshitaishvili, S.B. Smithson, C.M. Snelson, L.M. Stevens, A.R. Tyson, and M.L. Williams.
}

tive weakness, expressed as a tendency to be reactivated. Throughout much of the southern Rocky Mountains, seismic refraction data have delineated a 10-15 $\mathrm{km}$ thick, $7.0-7.5 \mathrm{~km} / \mathrm{s}$ mafic lower crustal layer. The base of this layer (Moho) varies from 40 to $55 \mathrm{~km}$ in depth. We interpret it to have formed diachronously and by a combination of processes, including original arc development and subsequent magmatic underplating, and to be the product of progressive evolution of the lithosphere.

\section{INTRODUCTION}

The CD-ROM (Continental Dynamics of the Rocky Mountains) experiment is a geological and geophysical study of a transect from Wyoming to New Mexico. The transect obliquely crosses Phanerozoic tectonic provinces (southern Rocky Mountains, Rio Grande rift, Great Plains) and orthogonally crosses northeast-striking structures related to Proterozoic assembly of the crust (Fig. 1). Our goal is to differentiate the lithospheric structures that formed during Precambrian growth and stabilization of the continent from those that record Cenozoic tectonism. CD-ROM integrates a series of coordinated seismic experiments (Keller et al., 1999) and geological studies to delineate crust and upper mantle structure and provide a better understanding of lithospheric evolution and geodynamical processes.

\section{GEOLOGIC AND SEISMIC EVIDENCE FOR THE AGE AND STRUCTURE OF THE ROCKY MOUNTAIN LITHOSPHERE}

Figure 1 shows the complex arrangement of Precambrian crustal provinces and younger tectonic elements of the southern Rocky Mountains. Similar to the crustal signature, mantle velocities also show complex patterns between highand low-velocity domains (Fig. 1). Figure 2 shows a multiscale cross section of the Rocky Mountain lithosphere. One of the most notable features on the cross section is the dramatic lateral velocity variations in the upper mantle. These velocity differences could be interpreted as reflecting temperature differences related to modern asthenospheric convection, and as such, even though the crust is predominantly Proterozoic, the upper mantle under the Rocky Mountains would be interpreted to be essentially Cenozoic. However, here we explore the hypothesis that the lithospheric mantle under the Rocky Mountains, although extensively modified and reactivated by younger events, is primarily Proterozoic in age. This is suggested by the congruence of dipping crust and mantle boundaries with major Proterozoic province boundaries at the surface. By this hypothesis, the observed seismic velocity variations reflect a complex overprinting, where Proterozoic compositional and mechanical heterogeneities influenced Cenozoic mantle magmatism and lithosphereasthenosphere interactions.

One of the most profound tectonic boundaries in the Rocky Mountain region is the Cheyenne belt (Fig. 1), a crustal manifestation of the suture between Archean crust and juvenile 1.8-1.7 Ga Proterozoic island arc crust (Hills and Houston, 1979). New seismic reflection images of the crust (Fig. 2B) confirm that the Cheyenne belt dips south under the Proterozoic Green Mountain arc (Condie and Shadel, 1984), consistent with northverging thrusting of Proterozoic rocks over Archean crust (Karlstrom and Houston, 1984; Chamberlain, 1998). However, reflection data (Morozova et al., 2002) show that the deeper crust is characterized by tectonic inter-wedging similar to other sutures between old continents and younger arcs (Cook et al., 1998) rather than subparallel, south-dipping shear zones. We speculate that the north-dipping reflections from the Farwell Mountain area (Fig. 2B) project through generally unreflective lower 
crust to coincide with a thrust-offset Moho seen in teleseismic receiver function images, and with the top of a highvelocity mantle anomaly (blue anomaly of Fig. 2D) that dips north under the Archean (Dueker et al., 2001). Our present interpretation is that Proterozoic oceanic lithosphere was underthrust beneath Archean crust during late stages of accretion of the Green Mountain arc but never developed into a self-sustaining subduction system, as shown by the absence of an associated volcanic arc to the north above it. This is similar to subduction polarity reversal taking place as the Banda arc accretes to Australia (Snyder et al., 1996). A series of south-dipping reflections (Lester Mountain suture) near the Farwell Mountain structure are interpreted as a suture zone between the 1.78-1.76 Green Mountain arc and the 1.75-1.72 Rawah arc-backarc complex (Fig. 2B). Dismembered ophiolitic fragments crop along this boundary zone.

The Aspen anomaly (Dueker et al., 2001) is an enigmatic low-velocity mantle anomaly that lies beneath the Colorado Mineral belt. (It is imaged by regional-scale studies and occupies part of the blank area of Figure 2D.) The Colorado Mineral belt is a northeaststriking zone defined by: a Proterozoic shear zone system (McCoy, 2001); a suite of Laramide-aged plutons and related ore deposits (Tweto and Sims, 1963); a major gravity low (Isaacson and Smithson, 1976); low-crustal velocities; and high heat flow (Decker et al., 1988). The presence of Laramide plutons here suggests that the mantle in this region was modified during the early Cenozoic and the high heat flow suggests continued, young heat sources.

The Jemez lineament (Fig. 1) marks the surface boundary between 1.8 and $1.7 \mathrm{Ga}$ crust of the Yavapai province (to the north) and 1.65 Ga crust of the Mazatzal province (Wooden and DeWitt, 1991; Shaw and Karlstrom, 1999). New reflection data (Magnani et al., 2001, Eshete et al., 2001; Fig. 2A) show southdipping middle crustal reflections that project toward a south-dipping boundary between fast (south) and slow (north) mantle that extends to great depth $(>200$ km; Fig. 2). Based on these relationships, we interpret the Jemez lineament to mark a Proterozoic suture zone that localized Cenozoic magmatism.

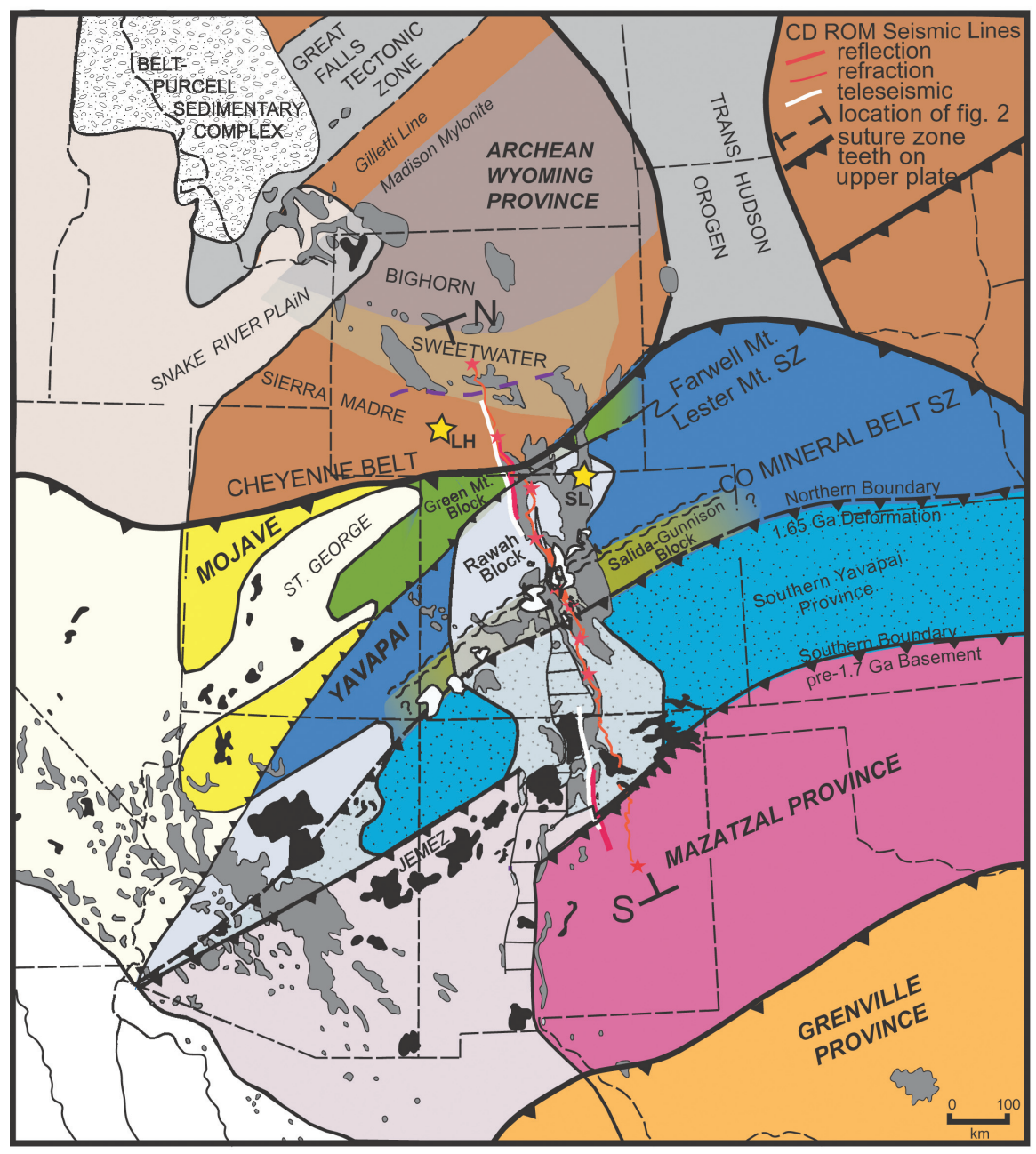

Figure 1. Geologic elements of southwestern North America showing Continental Dynamics of the Rocky Mountains (CD-ROM) reflection, refraction, and teleseismic lines. Precambrian provinces strike northeast, Laramide uplifts (gray) strike north-south, Laramide plutons (white) and Neogene volcanic fields (black) strike northeast. Locations of xenolith localities are shown as yellow stars. LH-Leucite Hills; SL-State Line district. Lithospheric mantle has lower velocity toward plate margin; area of lighter color represents regions underlain by low-velocity mantle, probably containing partial melt (from Dueker et al., 2001). In the Rocky Mountain-Colorado Plateau region, fingers of this hot mantle penetrate older lithosphere along northeast-striking zones; these areas are producing basaltic melts as shown by young volcanics along Yellowstone, St. George, and Jemez zones.

\section{SEISMIC AND GEOLOGIC EVIDENCE FOR THE NATURE OF THE LOWER CRUST}

This section examines seismic and geologic data from the crust, including new geophysical and xenolith data, and highlights the importance of understanding crust-mantle interactions through time. Figure $2 \mathrm{~B}$ shows a crustal velocity model that is based on the detailed CD-ROM refraction line (Rumpel et al., 2001; Snelson, 2001). The refraction data show appreciable topography on the Moho and a crust that varies from $\sim 40$ to $55 \mathrm{~km}$ thick. A notable feature is a high-velocity (7.0-7.5 $\mathrm{km} / \mathrm{s}$ ), variable-thickness (10-15 km), lower crustal layer beneath the Proterozoic terranes. These velocities are consistent with a dominantly mafic composition. The presence and geometry of this layer are well documented by both wide-angle reflection and refraction data, as well as by receiver function analysis. This zone appears unreflective on all of the seismic reflection lines.

Xenoliths have been recovered from the Stateline diatremes in the Proterozoic crust of northern Colorado and from highly potassic lavas from the Leucite Hills in the adjacent Archean crust of 
Figure 2. Synthesis of Continental Dynamics of the Rocky Mountains (CD-ROM) results. A. Line drawing of CD-ROM Jemez lineament reflection line (Magnani et al., 2001; Eshete et al., 2001) superimposed on receiver function image of Dueker et al. (2001). In receiver function images, red areas represent positive velocity gradients (velocity increases downwards) and blue areas represent negative velocity gradients. Jemez lineament separates oppositely dipping reflection systems. On basis of geologic correlations, we suggest that south-dipping reflections represent a $\sim 1.65$ Ga paleosubduction zone and north-dipping reflections represent a $\sim 1.4 \mathrm{Ga}$ extensional shear zone system. MTMora thrusts; PT-Pecos thrust. B. Line drawing of CD-ROM Cheyenne belt reflection line (Morozova et al., 2002) superimposed on receiver function image of Dueker et al. (2001); dashed blue line represents high-velocity body imaged by tomography ( $2 \%$ contour). AArchean lithosphere; P-Proterozoic lithosphere; Pgm—Proterozoic Green Mountain block; Prb-Proterozoic Rawah block; CB-Cheyenne belt; FM-Farwell Mountain zone; LMLester Mountain zone. C. Results from CD-ROM refraction experiment; interfaces at Moho and top of 7.0-7.5 $\mathrm{km} / \mathrm{s}$ layer are well resolved by wideangle reflections and refractions (Rumpel et al., 2001; Snelson, 2001); receiver function images (Dueker et al., 2001) are superimposed on refraction model and show good agreement for mafic lower crustal layer. D. Generalized geologic cross section superimposed on P-wave tomographic image of Dueker et al. (2001). Crustal structures in Cheyenne belt and Jemez lineament areas are generalized from seismic reflection data (above) with solid lines representing well-defined reflections. Locations of xenolith pipes shown as vertical lines. Dipping elements in tomographic image, combined with overlying crustal structures, are interpreted to be Proterozoic suture zones and North American lithosphere is interpreted to extend to $>200 \mathrm{~km}$ depth.

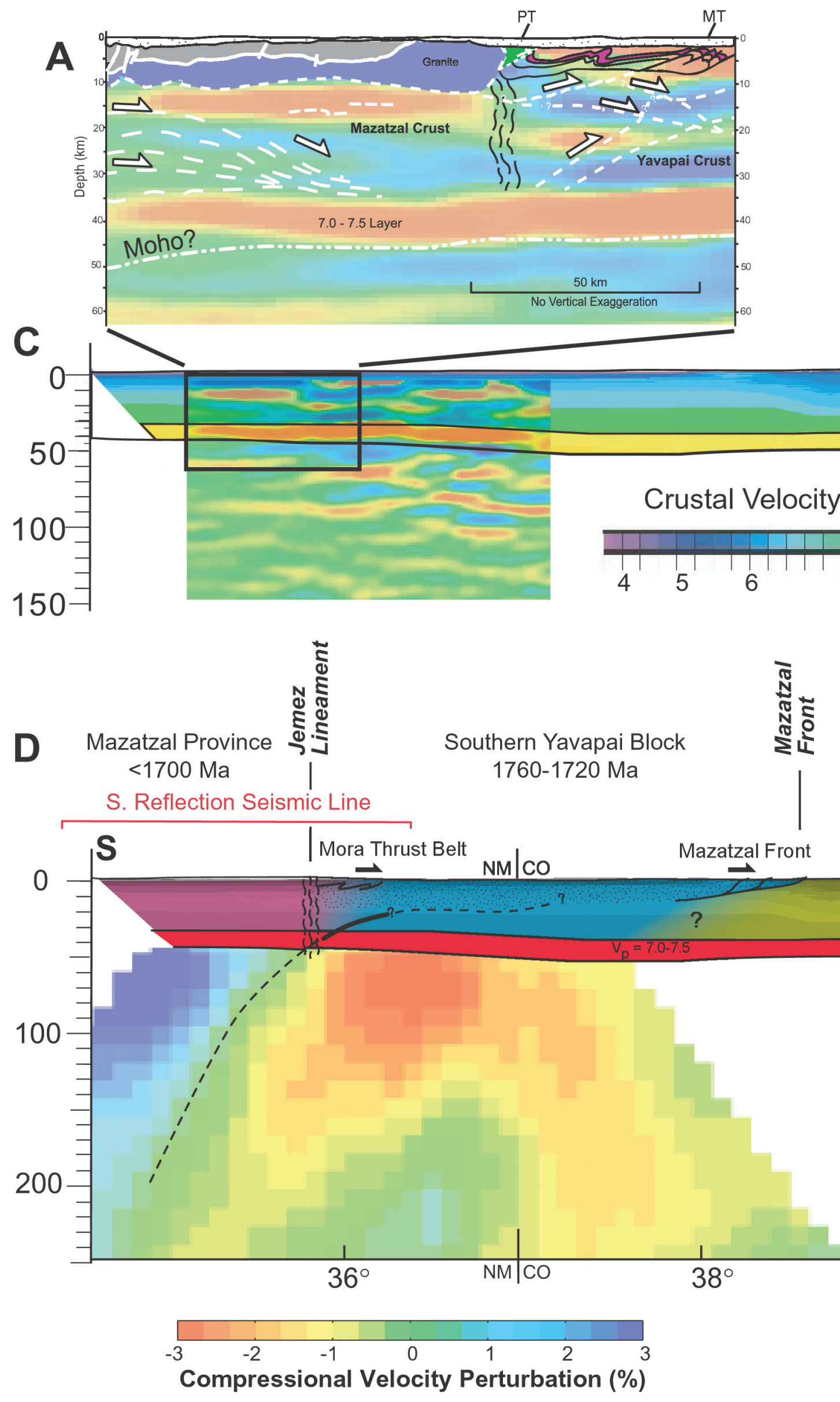




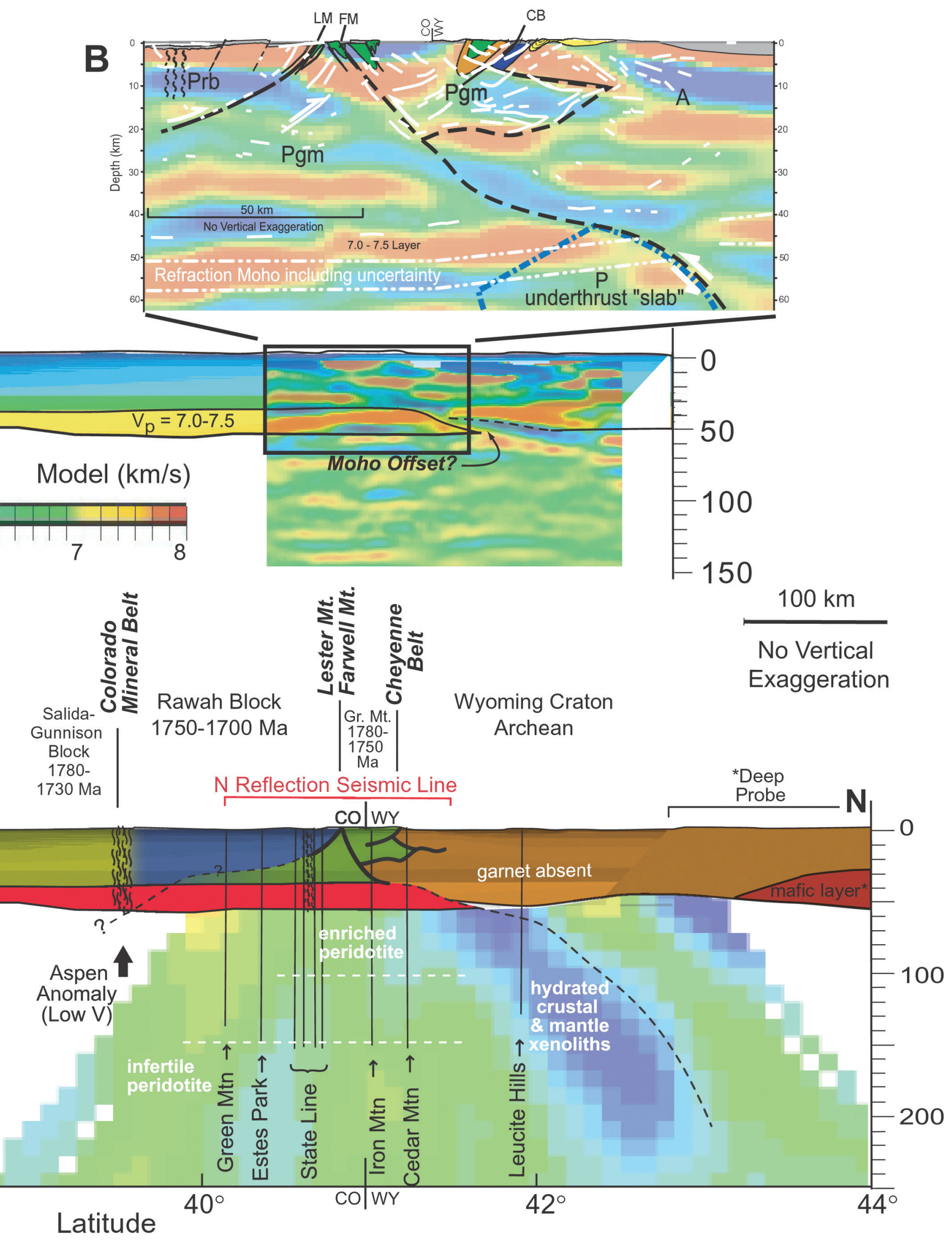


southern Wyoming (Figs. 1 and 2). Lower crustal xenoliths from the Archean side (from depths of $\sim 30 \mathrm{~km}$; 0.8-1.0 GPa) consist of relatively felsic hornblende-pyroxene gneisses (without garnet); they typically display a weak-to-strong foliation primarily defined by amphibole. These, and the mantle xenoliths from this locality, are more hydrated than the Proterozoic xenoliths to the south, perhaps compatible with a position above an underthrust oceanic slab (Fig. 2B). In contrast, the lower crustal xenoliths from the Proterozoic lithosphere (from depths of $\sim 40 \mathrm{~km} ; 1.2 \mathrm{GPa}$ ) contain little fabric and include garnet, two-pyroxene granulites, and rare eclogites, consistent with derivation from the thick, relatively dry, high-velocity mafic layer. Proterozoic lower crustal xenoliths record a more complex history than Archean xenoliths. $\mathrm{U}-\mathrm{Pb}$ zircon geochronology of Archean xenoliths yields dates that are similar to the crystallization ages of rocks exposed at the surface (ca. 2.6-2.7 Ga). In contrast, xenoliths from the Proterozoic side are ca. 1.65-1.7 Ga meta-igneous rocks that contain igneous and metamorphic zircons that yield a range of ages: Devonian (presumed to be the age of kimberlite eruption), ca. $500 \mathrm{Ma}, 1370$ $1420 \mathrm{Ma}, 1640-1750 \mathrm{Ma}$ (the dominant population), and Archean (grains as old as $3.1 \mathrm{Ga}$ ). The xenolith data indicate that crust and mantle provinces across the Cheyenne belt are distinct lithospheric entities that date back to the time of assembly (Eggler et al., 1987).

\section{REACTIVATION AND DIFFERENTIAL UPLIFT OF PROTEROZOIC LITHOSPHERE}

Geologic studies indicate that the Proterozoic lithosphere south of the Cheyenne belt was repeatedly reactivated, whereas the Archean lithosphere has been relatively stable (Karlstrom and Humphreys, 1998). Following protracted assembly of the lithosphere from 1.78 to $1.65 \mathrm{Ga}$, the first major reactivation event took place $\sim 1.4 \mathrm{Ga}$ and involved widespread bimodal magmatism and intracontinental transpressional deformation (Nyman et al., 1994). This event pervasively affected the Proterozoic lithosphere but essentially terminated at the Cheyenne belt.

In situ electron microprobe U-Pb dating of monazite (Williams et al., 1999)

helps document the importance of recurrent movements, and hence persistent weakness, within the Colorado Mineral belt (Shaw et al., 2001). Monazite geochronology from shear zones indicates two protracted, ca. 100 m.y. long, orogenic episodes (1.72-1.62 Ga and 1.45-1.35 Ga), each consisting of numerous pulses of deformation, plus $1.1 \mathrm{Ga}$ Paleozoic and Laramide movements (Allen, 1994). Ar-Ar data (Karlstrom et al., 1997; Shaw et al., 1999) corroborate previous documentation (Chamberlain and Bowring, 1990; Bowring and Karlstrom, 1990; Hodges and Bowring, 1995) that discrete crustal blocks throughout the southwestern United States show very different cooling histories due to differential uplift in the Mesoproterozoic and Neoproterozoic, controlled in part by accretionary structures. New fission-track studies demonstrate post-Laramide differential uplift across the Colorado Mineral belt (Kelley and Chapin, 2002). These

These data confirm and extend

the hypothesis of Tweto and Sims

(1963) that the Colorado Mineral

belt was a long-lived zone of weakness in the lithosphere.

data confirm and extend the hypothesis of Tweto and Sims (1963) that the Colorado Mineral belt was a long-lived zone of weakness in the lithosphere.

The extent and style of Phanerozoic reactivation of Proterozoic lithosphere were different between the Proterozoic and Archean lithospheric sections. For example, Ancestral Rocky Mountain uplifts formed almost exclusively south of the Cheyenne belt. Laramide deformation partially reactivated older boundaries in both areas, but minor fault analyses show a major change in style of Laramide to Holocene faulting across the Cheyenne belt. In the Archean lithosphere, paleostrain data indicate one or two directions of Laramide faulting and minimal subsequent deformation. In the Proterozoic lithosphere, data locally indicate three stages of Laramide faulting and three stages of Neogene faulting suggest- ing reactivations of a weaker Proterozoic crust (Koenig-Koenig, 2002).

\section{NEOGENE TECTONICS ACCOMPANIES REGIONAL DENUDATION}

A provocative hypothesis is that the mantle structures that we have imaged seismically may have distinct topographic manifestations. A combined topographicthermochronologic study by Pazzaglia and Kelley (1998) demonstrated that the mean local relief, mean elevation, and thermochronologically determined exhumation history vary systematically across both the Cheyenne belt and Jemez lineament. Furthermore, geomorphic studies suggest that there is contemporary uplift associated with the youthful magmatism concentrated along the Jemez lineament (Wisniewski and Pazzaglia, 2002). Here, the Canadian River has a distinct convexity or bulge in both its long profile and terrace profiles where it crosses the Jemez lineament and has a rate of incision about two times greater than similar reaches upstream or downstream of the lineament. Thus, in spite of the numerous complex processes that combine to shape landscapes, correlations such as this suggest that deep lithospheric structure exerts important controls on today's topography.

\section{DISCUSSION OF PROCESSES OF STABILIZATION AND EVOLUTION OF CONTINENTAL LITHOSPHERE}

Cratons are stabilized by thick lithospheric mantle that extends to depths of $>250 \mathrm{~km}$ and moves through weaker convecting asthenosphere. These mantle "keels" resist becoming incorporated into the asthenosphere because they are buoyant owing to the presence of strongly melt-depleted peridotite (Jordan, 1988). North America is an interesting case study because it contains one of the thickest mantle keels on the planet, and western North America (e.g., from the Canadian shield to the Pacific plate margin) contains the largest mantle-velocity gradient on Earth (Grand, 1994; Van der Lee and Nolet, 1997). Gradation from fast (cratonic) to slow (orogenic) upper-mantle velocity structure occurs over a remarkably short distance in the Rocky Mountains (Henstock et al., 1998) and this is therefore an important area to study the evolution of mantle structures. 
In addition to the complexity resulting from the Proterozoic assembly of the continent, understanding the Rocky Mountain transect (Wyoming to New Mexico) requires consideration of Cenozoic modifications to the lithosphere. Some workers have postulated that the mantle had been largely removed (Bird, 1988) or preserved to moderate depths (70-100 km; Livicarri and Perry, 1993) by shallow-angle subduction of the Farallon slab in the Laramide. Further, many workers have postulated an upwelling of asthenosphere-to-shallow depth (even to the base of the crust) following removal of the Farallon slab that caused the ignimbrite flare-up (e.g., Humphreys, 1995). However, if the Proterozoic lithosphere is thicker, as we suggest, another possibility is that, rather than complete removal, the upper mantle was modified by a combination of Cenozoic events, including hydration above a Laramide flat slab and lithosphere-asthenosphere interactions that caused the ignimbrite flare-up and Neogene magmatism and high heat flow. If the low-velocity upper mantle in the southern Rocky Mountain region is old and essentially intact (e.g., below the Colorado Mineral belt and Jemez lineament), then this mantle, although hot and weak and perhaps being invaded by asthenosphere-derived melts, has not yet been entrained in the convecting asthenosphere. Thus, one important unresolved question is the depth extent of western North American lithosphere and the relative contributions of modern thermal differences and ancient compositional heterogeneity in the present velocity structure.

Another issue is to explain the distinctive Proterozoic lithosphere. The recurrent reactivation of the Proterozoic lithosphere suggests long-lived weakness, relative to Archean lithosphere. We speculate that this fundamental difference is a result of the style of accretion. The Proterozoic orogen was rapidly assembled from oceanic terranes with no major continent-continent collisions, in contrast to much of the Archean and Proterozoic lithosphere to the north. The Proterozoic lithospheric mantle appears to be distinct mechanically because it is buoyant, thick, and strongly segmented. Thus, even prior to the Laramide event, this lithosphere may have been pervasively hydrated during Proterozoic subduction-accretion processes associated with assembly of numerous small bits of juvenile lithosphere, similar to the ongoing accretion of Indonesian oceanic terranes to Australia. Possibly, it is this spatially variable hydration that originally gave rise to the compositional domains imaged in today's mantle.

The genesis of the high-velocity lower crustal layer is not well understood, but it probably had a complex origin involving multiple episodes of segregation of crustal cumulates, concentration of refractory residues of partial melting, and addition of underplated and/or intruded material. In the Proterozoic part of the CD-ROM cross section (Fig. 2D), we suggest that the $7.0-7.5 \mathrm{~km} / \mathrm{s}$ lower crustal layer may in part be a record of a series of mantle depletion events that extracted basaltic melt from the lithospheric mantle and transferred it to the vicinity of the existing Moho, creating a lower crustal layer that is mafic but that may also contain some ultramafic material. If so, the Moho and the lower crustal layer are younger than the assembly structures and provide a record of changing crustal thickness. The lower crustal layer is remarkably featureless on regional reflection profiles and lies below well-developed bright reflectivity that we interpret to be a record of Proterozoic plate tectonics. Our hypothesis is that today's thick Proterozoic crust grew in part by underplating and addition of mafic intrusive bodies of a variety of ages. Based on thinning of the lower crustal layer just north of the Cheyenne belt, the relative lack of Proterozoic overprinting of Archean lower crust to the north, and volumetrically minor Phanerozoic magmatism in the Archean lithosphere, this process seems to have preferentially affected the Proterozoic lithosphere. A key time for such underplating was ca. 1.4 Ga. Petrogenetic models suggest that the large volume of $\sim 1.4$ Ga granitic magmatism in the middle crust was related to melting of rocks with a tholeiitic basalt composition (Frost and Frost, 1997), implying that an enormous volume of mafic rock may reside in the lower crust. However, only a single 1.4 Ga metamorphic zircon has been found so far in the Proterozoic lower crustal xenoliths, and the geochronological and $\mathrm{Nd}$ isotopic data from mafic lower crustal xenoliths throughout the southwestern
United States indicate that these xenoliths were derived primarily from $1.7 \mathrm{Ga}$ crust. Thus, another major unresolved problem is to understand the role of mafic underplating in forming the lower crustal layer and restructuring the Moho.

\section{SUMMARY}

The combined geophysical and geologic data from the CD-ROM experiment provide a high-resolution, multiscale image of the lithosphere of the Rocky Mountain region. This image supports the hypothesis that the lithospheric architecture of the southwestern United States produced during Proterozoic assembly of juvenile terranes provided the template for today's lithospheric structure. The integrated data set indicates that the Cheyenne belt, the Farwell-Lester Mountain zone, and the Jemez lineament, and their corresponding velocity anomalies in the mantle (to $>200 \mathrm{~km}$ ), are controlled by Paleoproterozoic subduction zones that were active during collisions of juvenile terranes. A variable-thickness, high-velocity lower crustal layer forms the base of the crust under all of the Proterozoic provinces investigated along the CD-ROM corridor. This and the appreciable Moho topography are interpreted to be, at least in part, younger than the sutures and the result of underplating that took place at 1.7, 1.4, and $1.1 \mathrm{Ga}$ and more locally at several times in the Phanerozoic. Additional geochronological, isotopic, and physical property investigations of crustal xenolith populations will be required to test this hypothesis. Two provocative and testable hypotheses concerning lithospheric evolution are: (1) the lithospheric mantle in the southern Rocky Mountains preserves old subduction structures, is thick ( $>200$ $\mathrm{km}$ ) and has been persistently weak, and (2) the lowermost crust is a record of progressive evolution of the lithosphere and has grown through several underplating and/or intrusive events.

\section{ACKNOWLEDGMENTS}

The CD-ROM experiment was funded by the National Science Foundation Continental Dynamics Program (19972001). The refraction experiment was cofunded by the German National Science Foundation. We thank Rick Carlson, Dave Snyder, Paul Morgan, and Art Snoke for helpful reviews. 


\section{REFERENCES CITED}

Allen, J.L., III, 1994, Stratigraphic variations, fault rocks, and tectonics associated with brittle reactivation of the Homestake shear zone, central Colorado [Ph.D. thesis]: Lexington, Kentucky, University of Kentucky, 321 p.

Bird, P., 1988, Formation of the Rocky Mountains, western United States: A continuum computer model: Science, v. 239, p. 1501-1507.

Bolay-Koenig, N.V., 2001, Phanerozoic deformation in the southern Rocky Mountains, USA: A kinematic analysis of minor faults in north-central New Mexico and regional GIS analyses [M.S. thesis]: Fort Collins, Colorado, Colorado State University, $159 \mathrm{p}$

Bowring, S.A., and Karlstrom, K.E., 1990, Growth and stabilization of Proterozoic continental lithosphere in the southwestern United States: Geology, v. 18, p. 1203-1206.

Chamberlain, K.R., 1998, Medicine Bow orogeny: Timing of deformation and model of crustal structure produced during continent-arc collision, ca. $1.78 \mathrm{Ga}$, southeastern Wyoming: Rocky Mountain Geology, v. 33, p. 259-277.

Chamberlain, K.R., and Bowring, S.A., 1990, Proterozoic geochronologic and isotopic boundary in NW Arizona: Journal of Geology, v. 98, p. 399-416.

Condie, K.C., and Shadel, C.A., 1984, An early Proterozoic arc succession in southeastern Wyoming: Canadian Journal of Earth Sciences, v. 21, p. 415-427.

Cook, F.A., van der Velden, A.J., Hall K.W., and Roberts, B.J., 1998, Tectonic delamination and subcrustal imbrication of the Precambrian lithosphere in northwestern Canada mapped by LITHOPROBE: Geology, v. 26, p. 839-842

Decker, E.R., Heasler, H.P., Buelow, K.L., Baker, K.H., and Hallin, J.S., 1988, Significance of past and recent heat flow and radioactivity studies in the southern Rocky Mountains region: Geological Society of America Bulletin, v. 100, p. 1851-1885.

Dueker, K., Yuan, H., and Zurek, B., 2001, Thick Proterozoic lithosphere of the Rocky Mountain region: GSA Today, v. 11, no. 12 , p. 4-9.

Eggler, D.H., Meen, J.K., Welt, F., Dudas, F.O., Furlong, K.P., McCallum, M.E., and Carlson, R.W., 1987,

Tectonomagmatism of the Wyoming province, in Drexler, J.W., and Larson, E.E., eds., Cenozoic volcanism in the southern Rocky Mountains revisited: A tribute to Rudy C. Epis: Colorado School of Mines Quarterly, v. 83, p. 25-40.

Eshete, T., Miller, K.C., Levander, A., and Magnani, M.B., 2001, Seismic imaging of the Yavapai-Mazatzal province boundary in northeastern New Mexico: Results from CDROM and industry profiles: Geological Society of America Abstracts with Programs, v. 33, no. 5, p. A-43.

Frost, C.D., and Frost, B.R., 1997, Reduced rapakivi-type granites: The tholeitic connection: Geology, v. 25, p. 647-650.

Grand, S.P., 1994, Mantle shear structure beneath the Americas and surrounding oceans: Journal of Geophysical Research, v. 99, p. 11591-11621.

Henstock, T.J., and the Deep Probe Working Group, 1998, Probing the Archean and Proterozoic lithosphere of western North America: GSA Today, v. 8, no. 7, p. 1-5, 16-17.

Hills, F.A., and Houston, R.S., 1979, Proterozoic tectonics of the central Rocky Mountains, North America: University of Wyoming, Contributions to Geology, v. 17, p. 89-109.
Hodges, K.V., and Bowring, S.A., 1995, ${ }^{40} \mathrm{Ar} /{ }^{\beta 9} \mathrm{Ar}$ thermochronology of isotopically zoned micas: Insights from the southwestern USA Proterozoic orogen: Geochemica Cosmochemica Acta, v. 59, p. 3205-3220.

Humphreys, E.D., 1995, Post-Laramide removal of the Farallon slab, western United States: Geology, v. 23, p. $987-990$

Isaacson, L.B., and Smithson, S.B., 1976, Gravity anomalies and granite emplacement in west-central Colorado: Geological Society of America Bulletin, v. 87, p. 22-28.

Jordan, T.H., 1988, Structure and formation of the continental tectosphere: Journal of Petrology, v. 29, p. 11-37.

Karlstrom, K.E., and Houston, R.S., 1984, The Cheyenne Belt: Analysis of a Proterozoic suture in southern Wyoming: Precambrian Research, v. 25, p. 415-446.

Karlstrom, K.E., and Humphreys, E.D., 1998, Persistent influence of Proterozoic accretionary boundaries in the tectonic evolution of southwestern North America: Interaction of cratonic grain and mantle modification events: Rocky Mountain Geology, v. 33, p. 161-179.

Karlstrom, K.E., Dallmeyer, D.A., and Grambling, J.A., 1997, ${ }^{40} \mathrm{Ar}{ }^{\beta 9} \mathrm{Ar}$ evidence for $1.4 \mathrm{Ga}$ regional metamorphism in northern New Mexico: Implications for thermal evolution of the lithosphere in the southwestern U.S.A.: Journal of Geology, v. 105, p. 205-223.

Keller, G. R, Karlstrom, K.E, and Farmer, G.L, 1999 Tectonic evolution in the Rocky Mountain region: 4-D imaging of the continental lithosphere: Eos (Transactions, American Geophysical Union), v. 80, p. 493, 495, 498.

Kelley, S.A., and Chapin, C.E., 2002, Denudational histories of the Front Range and Wet Mountains, Colorado, based on apatite fission-track thermochronology, in Cather, S.M., et al., eds., Tectonics, geochronology, and volcanism in the southern Rocky Mountains and Rio Grande rift: New Mexico Bureau of Mines and Mineral Resources Bulletin, in press.

Livaccari, R.F., and Perry, F.V., 1993, Isotopic evidence for preservation of Cordilleran lithospheric mantle during the Sevier-Laramide orogeny, western United States: Geology, v. 21, p. $719-722$.

Magnani, M.B., Levander, A, Miller, K.C., and Eshete, T., 2001, Seismic structure of the Jemez lineament, New Mexico: Evidence for heterogeneous accretion and extension in Proterozoic time and modern volcanism: Eos (Transactions, American Geophysical Union), v. 82, p. F865

McCoy, A.M., 2001, The Proterozoic ancestry of the Colorado Mineral belt: Ca. 1.4 Ga shear zone system in central Colorado [M.S. thesis]: Albuquerque, New Mexico, University of New Mexico, $140 \mathrm{p}$.

Morozova, E.A., Wan, X., Chamberlain, K.R., Smithson, S.B. Johnson, R.A., Karlstrom, K.E., Tyson, A.R., Morozov, I.B., Boyd, N.K., and Foster, C.T., 2002, Geometry of Proterozoic sutures in the central Rocky Mountains from seismic reflection data: Cheyenne belt and Farwell Mountain structures: Geophysical Research Letters, in press.

Nyman, M., Karlstrom, K.E., Graubard, C., and Kirby, E., 1994, Mesoproterozoic contractional orogeny in western North America: Evidence from ca. 1.4 Ga plutons: Geology, v. 22, p. 901-904.
Pazzaglia, F.J., and Kelley, S.A., 1998, Large-scale geomorphology and fission-track thermochronology in topographic and exhumation reconstructions of the southern Rocky Mountains: Rocky Mountain Geology, v. 33, p. 229-257.

Rumpel, H., Snelson, C.M., Prodehl, C., Keller, G.R., and Miller, K.C., 2001, Results of the refraction/wide angle reflection seismic experiment in the southern Rocky Mountains (CD-ROM'99): Eos (Transactions, American Geophysical Union), v. 82, p. F640.

Shaw, C.A., and Karlstrom, K.E., 1999, The YavapaiMazatzal crustal boundary in the southern Rocky Mountains: Rocky Mountain Geology, v. 34, p. 37-52.

Shaw, C.A., Snee, L.W., Selverstone, J., and Reed, J.C., Jr. $1999,{ }^{40} \mathrm{Ar} /{ }^{39} \mathrm{Ar}$ thermochronology of Mesoproterozoic metamorphism in the Colorado Front Range: Journal of Geology, v. 107 , p. 49-67.

Shaw, C.A., Karlstrom, K.E., Williams, M.L., Jercinovic, M.J., and McCoy A., 2001, Electron microprobe monazite dating of ca. 1710-1630 Ma and ca. 1380 Ma deformation in the Homestake shear zone, Colorado: Origin and early evolution of a persistent intracontinental tectonic zone: Geology, v. 29, p. 739-742.

Snelson, C.M., 2001, Investigating crustal structure in western Washington and in the Rocky Mountains: Implications for seismic hazards and crustal growth [Ph.D. thesis]: El Paso, Texas, University of Texas, $234 \mathrm{p}$.

Snyder, D.B., Prasetyo, H., Blundell, D.J., Pigram, C.J., Barber, A.J., Richardson, A., and Tjokosaproetro, S., 1996, A dual doubly vergent orogen in the Banda Arc continent-arc collision zone as observed on deep seismic reflection profiles: Tectonics, v. 15, p. 34-53.

Tweto, O., and Sims, P.K., 1963, Precambrian ancestry of the Colorado Mineral Belt: Geological Society of America Bulletin, v. 74, p. 991-1014.

Van der Lee, S., and Nolet, G., 1997, Upper mantle S velocity structure of North America: Journal of Geophysical Research, v. 102, p. 22815-22838.

Williams, M.L., Jercinovic, M.J., and Terry, M.P., 1999, Age mapping and dating of monazite on the electron microprobe: Deconvoluting multistage tectonic histories: Geology, v. 27, p. 1023-1026.

Wisniewski, P.A., and Pazzaglia, F.J., 2002, Epeirogenic controls on the Canadian River incision and landscape evolution, High Plains of northeastern New Mexico: Journal of Geology, v. 110 , no. 4 , in press.

Wooden, J.L., and DeWitt, E., 1991, Pb isotopic evidence for the boundary between the early Proterozoic Mojave and central Arizona crustal provinces in western Arizona, in

Karlstrom K.E., ed., Proterozoic geology and ore deposits of Arizona: Arizona Geological Society Digest 19, p. 27-50.

Manuscript received January 4, 2002;

accepted January 28, 2002.
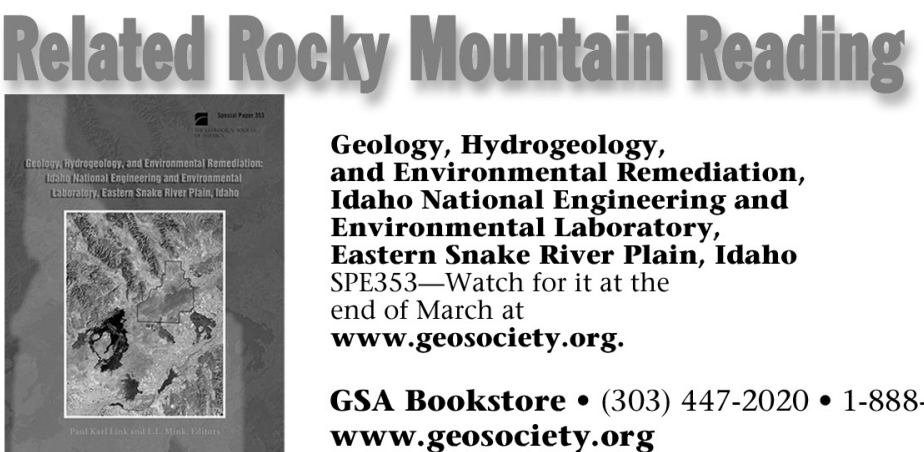

Geology, Hydrogeology, and Environmental Remediation Idaho National Engineering and Environmental Laboratory Eastern Snake River Plain, Idaho SPE353-Watch for it at the end of March at www.geosociety.org.

GSA Bookstore • (303) 447-2020 • 1-888-443-4472 www.geosociety.org

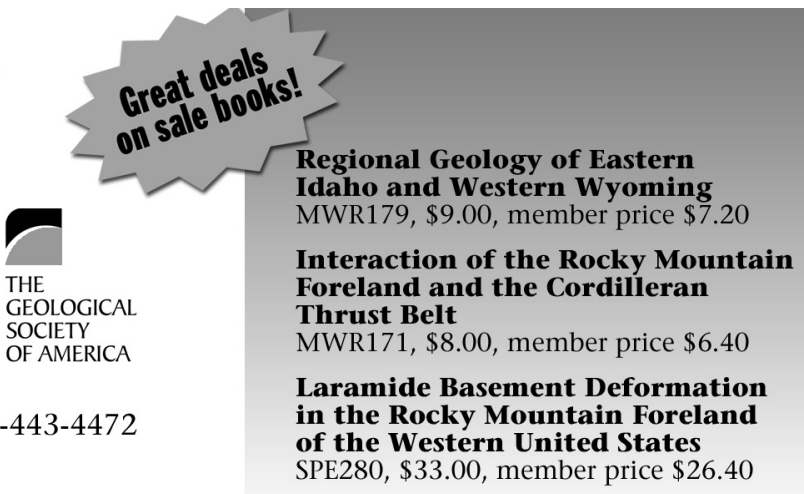

